\title{
FEASIBILITY OF REPURPOSING EXISTING AND ABANDONED HYDROCARBON WELLS IN THE FORM OF A GEOTHERMAL WELL-TRIPLET SYSTEM
}

\author{
Dávid Bretán \\ senior advisor, Mining and Geological Survey of Hungary \\ 1145 Budapest, Columbus u. 17-23.e-mail: bretan.david@mbfsz.gov.hu \\ Péter Szücs \\ professor, University of Miskolc, Faculty of Earth Science and Engineering \\ Institute of Environmental Management \\ 3515 Miskolc, Miskolc-Egyetemváros, e-mail: hgszucs@uni-miskolc.hu \\ Rita Miklós \\ assistant research fellow, University of Miskolc, Faculty of Earth Science and Engineering \\ Institute of Environmental Management \\ 3515 Miskolc, Miskolc-Egyetemváros, e-mail: hgmr@uni-miskolc.hu \\ Csaba Ilyés \\ assistant research fellow, University of Miskolc, Faculty of Earth Science and Engineering \\ Institute of Environmental Management \\ 3515 Miskolc, Miskolc-Egyetemváros, e-mail: hgilyes@uni-miskolc.hu
}

\begin{abstract}
There are various types of extraction and utilization possibilities of geothermal energy, of which a large group is energy recovery. The development of this sector is slow mainly due to its high initial investment demand and the long planning phase. The overall goal of the present research is cutting the cost of the drilling phase as the most expensive part of the establishment by repurposing unused and abandoned hydrocarbon wells. The article assesses the feasibility of a geothermal well-triplet system chosen to be the most promising technique amongst several utilization possibilities depending on the characteristics of both the geological media and the method itself. From the 14 examined abandoned wells three were found to be suitable based on their current condition and distance from each other. The mentioned technique requires an adequately porous and permeable media which was not provided by the initial depth of the wells, thus the considerable option left was to overdrill the existing wells till they reach the target geology, the known fractured karstic aquifer below. The current study summarizes the final results of a long-going research, from the geographical-, lithological surveys till the potential heat-transport modeling. As an outcome of a hydrodynamic-, and geothermal modeling, the feasibility of the repurposed, well-triplet system under specific boundary conditions has been proven. This article supports the final aspirations of a further going research project as an integral part of it carried out by the University of Miskolc.
\end{abstract}

Keywords: geothermal energy, hydrocarbon, well, triplet, abandoned, heat utilization, repurpose, modelling, overdrill 


\section{Subsurface modeling for long-term feasibility}

For investigating heat recovery via groundwater exploitation, a well-triplet was established with two injections and-, one production well setup. Based on existing and operating thermal karst water wells in the area and literature information the chosen target geology for the mentioned system is an Eocene age limestone aquifer. From one hand, datasets from operating thermal wells nearby confirm its location, on the other hand the geological history of the area also refers to the Eocene age limestone as a "well-charred" rock body [1]. Knowing the distance of the wells, and additional hydraulic properties of the upper limestone body two options arose. One was to inspect the system response by extracting and re-injecting in the same layer, and the other is to re-inject one layer below, a Triassic age limestone body. However, the properties of the Triassic age limestone layers situated below are poorly assessed. Therefore, according to the information about the two distinct aged rock body the decision was made and the most feasible idea was to implement a circulation system within the same Eocene age limestone layer.

In order to assess the long-term sustainability of the exploitation system, a continuous 50 years production-injection period was set with the pumping rates as seen in Table 1 . The aquifer layer is a well-karstified rock body with excellent (water bearing capacity and) hydraulic conduction properties. Therefore, the assumption was made that the system withstands the same amount of re-injected water distributed between two wells as it was withdrawn by one. The operation periods were specified as a one year long steady state phase to stabilize the system, then operating (transient) throughout 5-, 10-, 25-, 50 years long, examining the head changes at different distances from the wells.

\begin{tabular}{|c|c|c|c|c|c|c|}
\hline Well_ID & $\begin{array}{c}\text { Aquifer thickness } \\
{[\mathrm{m}]}\end{array}$ & $\begin{array}{c}\mathrm{Q} \\
{\left[\mathrm{m}^{3} / \mathrm{d}\right]}\end{array}$ & \multicolumn{2}{|c|}{$\begin{array}{c}\text { Screened depth range } \\
{[\mathrm{m}]}\end{array}$} & $\begin{array}{c}\text { Screened length } \\
{[\mathrm{m}]}\end{array}$ & $\begin{array}{c}\text { Water } \\
\text { temperature }\left[{ }^{\circ} \mathrm{C}\right]\end{array}$ \\
\hline W_23 & 37,3 & 1000 & 625 & 646,3 & 21,3 & 25 \\
\hline W_28 & 23,8 & 1000 & 605 & 618,88 & 13,8 & 25 \\
\hline W_35 & 23,8 & -2000 & 711 & 724,88 & 13,8 & 60 \\
\hline
\end{tabular}

Table 1. Aquifer parameters of extraction and injection wells (author's own work) Összefoglalás

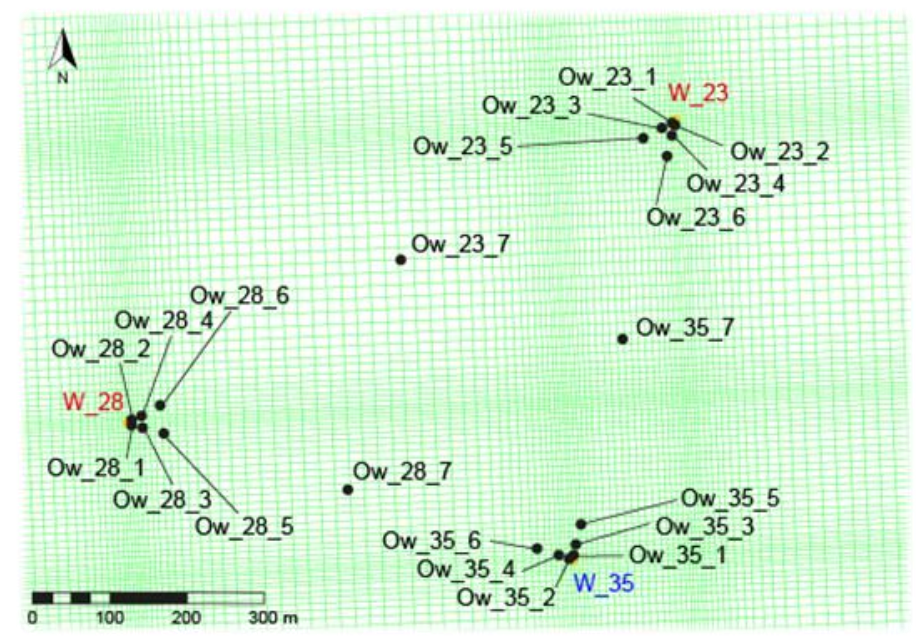

Figure 1. Cropped 2D view of observation well locations in the aquifer layer (author's own work) 
The monitoring points were set up systematically in equidistant points between the three wells, in order to be able to observe continuously the hydraulic changes in the system during production and injection. The specific distances in-between were measured, distributed denser around the wells then becoming more distant as moving away towards another (Fig. 1). This first section intended to achieve a better understanding and place the results of Section 2 and 3 in space (Fig. 2-5).

\section{Groundwater modeling of the research area}

The groundwater modeling was carried out as described previously in Section 1. The results of head changes are plotted for each well in the observation locations specified in Figure 1. The results of groundwater modeling shown that the heads stabilize after 1 year of operation and remain constant with the same rate of exploiting and re-injecting throughout a period of 50 years. Therefore, it can be stated that circulating the same amount of water in such pressurized aquifer layer under relatively constant conditions results in a long-term sustainable system.

The cone of depression showed in Figure 2 in case of injection well W-28 its up-coning is greater than in injection well $\mathrm{W}-23$, which is caused probably due to the shorter $(\Delta \mathrm{L}=-14,5 \mathrm{~m})$ screen length of the latter one. The effect of wells on each other is clearly visible on the shape of the equipotential circles around the wells (Fig. 2), which changes in time and space were also quantified. The drawdown maximum settled in $-7,4 \mathrm{~m}$ and for the up-coning maximum of the reinjection at $+3,6 \mathrm{~m}$ (Fig. 2).

The access times are equal to the length of operational periods visualizing the paths of water in the aquifer layer separately for exploitation and re-injection wells (but running simultaneously). The tracks of particles for each time-steps (1-, 5-, 10-, 25-, 50 years) were assessed. Not all these cited arrival times are carrying great importance for the subsequent heat transport modeling and also due to the volumetric limitations of the article, these results are not presented here. Keeping sustainability in mind, the less a system cools back by re-injection of the cold water the more sustainable it is.

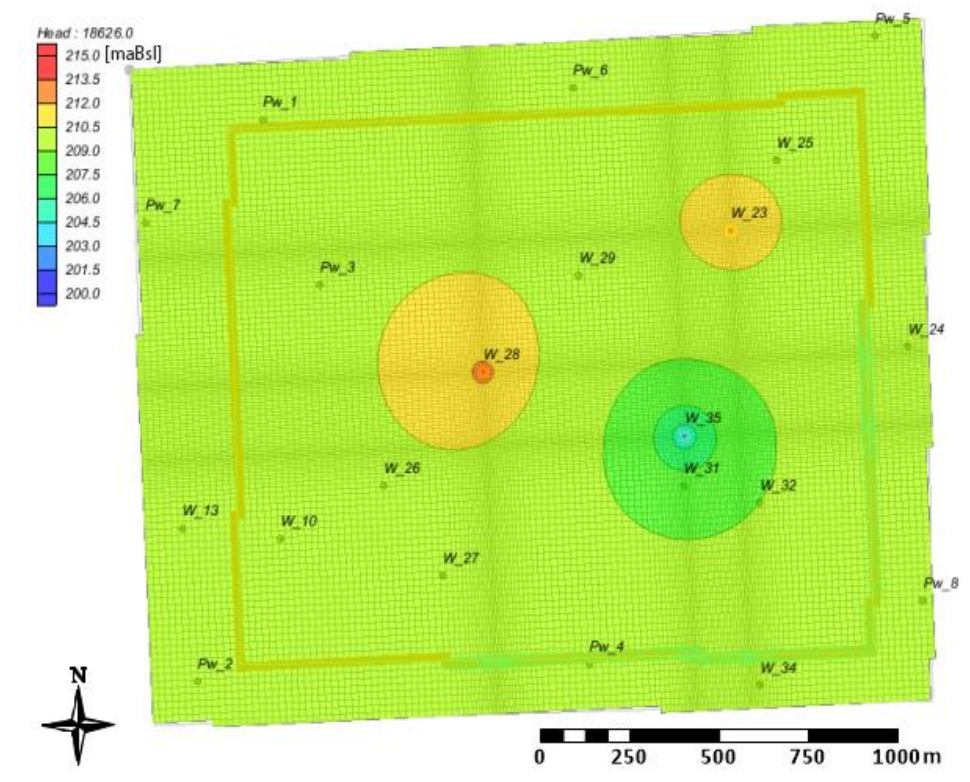

Figure 2. Stabilized heads in the aquifer layer at the end of the 50 years constant operation period (author's own work) 


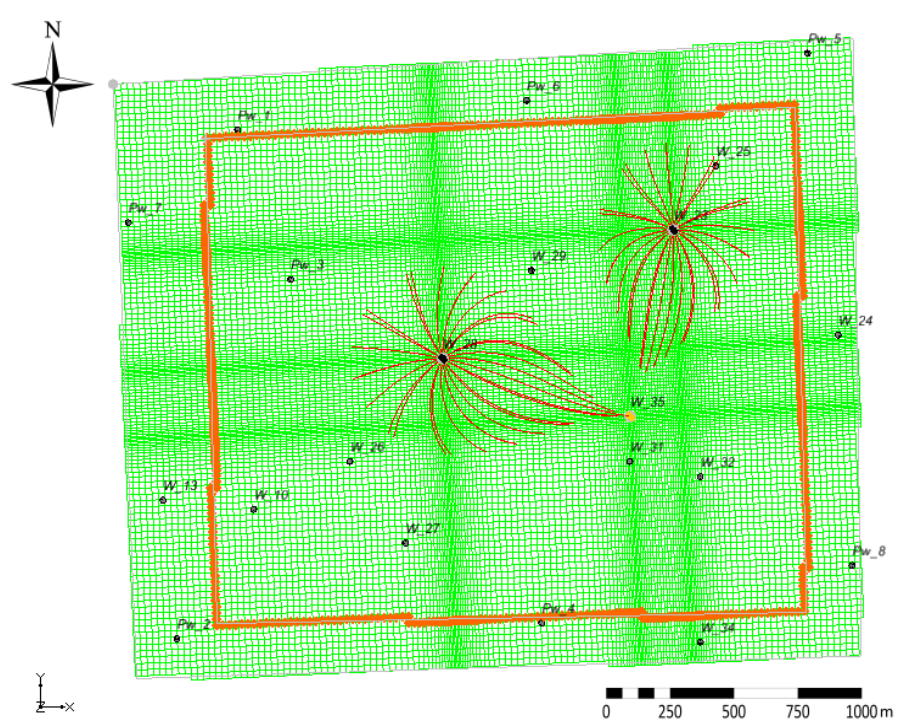

Figure 3. 1600 days breakthrough of the injection wells (author's own work)

Therefore, knowing when the injected (in this case cold) particles reach the production well could give a good estimation for a long-term sustainability from the side of heat transport phenomena. The mentioned time of reach, called breakthrough time showed in Figure 3. According to the groundwater model's calculations, with $2000 \mathrm{~m} 3$ /day discharge and recharge rate, the injected $\left(25^{\circ} \mathrm{C}\right.$ temperature $)$ water reaches the extraction well in 1600 days which is approximately 4,4 years. Thus, however the system appears to be hydrodynamically stable, for the above reason a relatively rapid recoil is expected in the forerunner.

\section{Heat transport modeling of the research area}

The heat transport modeling was also carried out as described in Section 1 using the calculated results of preliminary assessments and previously modelled groundwater movement presented in Section 2. The temperature distributions are plotted for each well in the same observation locations introduced on Fig. 1. The operational circumstances were the same in both cases, but the results of heat transport (temperature distribution) shows a more varied/less stable outcome in time and space than in case of the former groundwater model. As it was mentioned earlier, the amount of circulated water is the same, but with attached averaged temperature data (Tab. 1) and additional heat parameters.

As the system was considered to be hydrodynamically stable, a constant natural replenishment of $54,7{ }^{\circ} \mathrm{C}$ hot water was assumed (estimated from preliminary subsurface modeling of PetroMod software and additional temperature gradient calculations) throughout the whole (50 years) operation period. The heat transport of the subsurface aquifer media was performed with and exploited $61,6{ }^{\circ} \mathrm{C}$ through well W-35, and a cooled down re-injected $25^{\circ} \mathrm{C}$ water through well W-23 and W-28 (Tab. 1). All three screened sections in the wells are situated in the same aquifer layer but the exploitation takes place at a greater depth than the injection as the presumed limestone layers are tilted in a southeastern direction. As the injection wells are situated approximately at the same depth but with a different screen length the temperature of $54,7{ }^{\circ} \mathrm{C}$ were determined as an average temperature in the rock body around them (Tab. 1). The groundwater model showed that the first injected particles reach the production point in 1600 days (Fig. 2). This may lead to the mentioned perquisite conclusion that with 
a constant rate of operation, the system would cool down in a relatively short time and the long-term feasibility cannot be achievable.

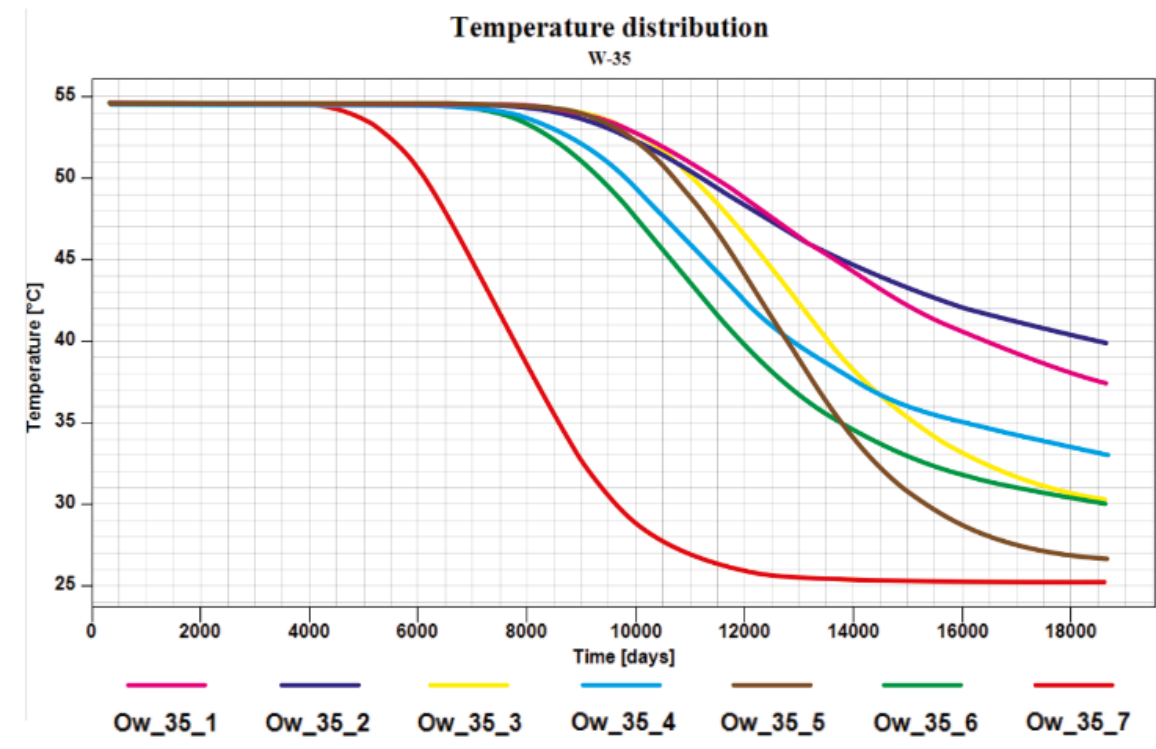

Figure 4. Temperature distribution in the vicinity of production well W-35 (author's own work)

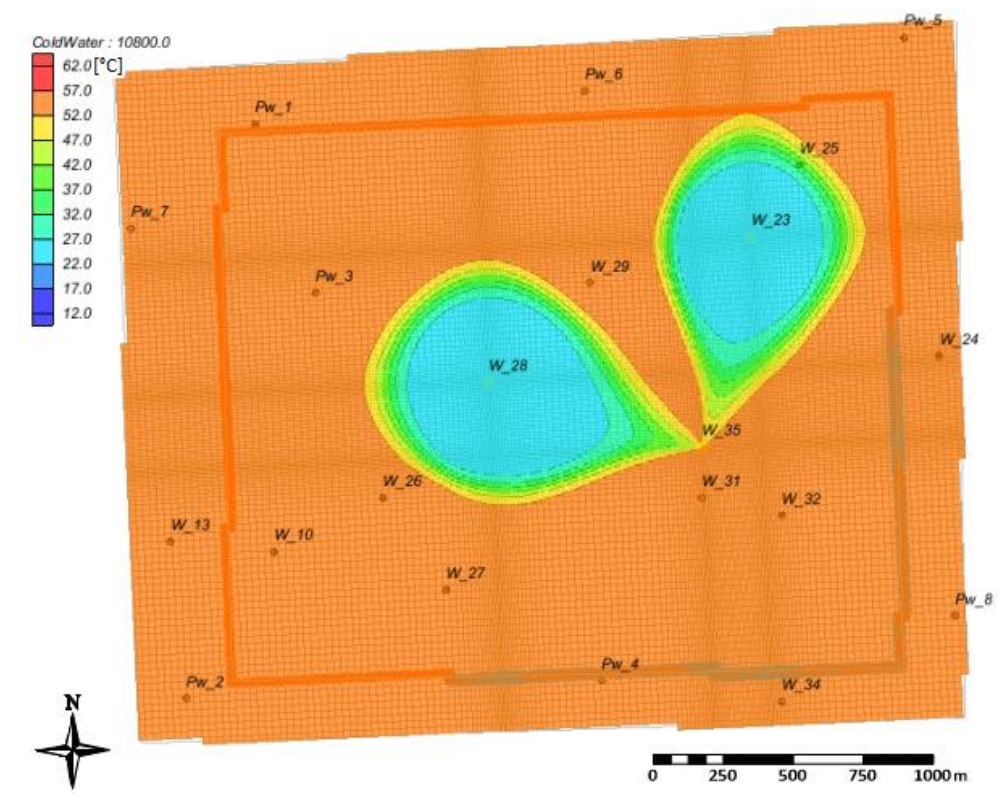

Figure 5. 10800 days heat breakthrough of the injection wells (author's own work)

As mentioned above the heat transport phenomena was assessed though 50 years. From the aspect of feasibility, the most significant information is provided by the reach out times of cold water plumes (Fig. 5). As Figure 3 shows the injected particles reach the point of exploitation in less than 5 years, but the effect of cold water only appears in 10800 days ( 29,6 years) (Fig. 4). It means that however 
the first particles appear earlier, the temperature decrease in the exploited water expected after 30 years of operation (Fig. 4-5). The life expectancy of a geothermal system highly depends on the manner of utilization and additional environmental circumstances. The average lifespan of heat pump systems is usually over 20-, somewhere between $25-50$ years [2]. The observation locations were the same for both modeling, logging different parameters (Fig. 1).

\section{Future plans}

The present study investigated the feasibility of a three-welled circulation system without taking into account the effects of the actual operational variability. For example, utilizing the present system connected to the utility network via a heat exchanger, several, multistep losses and operational difficulties could occur. As every system and utilization practice has its own specificity, the operation parameters must also be adjusted accordingly. In case of realistic simulation, implementing the modelled system for a referred heating purpose in a conjoined manner, every fluctuation of the network would be specified and taking into account. From the modeling side, it means an adaptation to the heating needs (increased during winter) including different production periods caused by seasonal variability. Introducing such periodicity into the operational conditions could have either a positive or negative feedback on the system and its environment. The previous example allows a more realistic sustainability study for a karst environment based heating system to be tested [3].

\section{Summary}

The basic premise was a revitalization idea of former oil producer wells in a mountainous region. Based on both international trends and also on the assessed country's potential resources, the possibility of geothermal utilization was chosen. The first part of this recent work was a preliminary assessment of the sample area for future studies and potentials to be explored during which topographic and geologic interpretation of the region through both geological and temperature distribution cross sections were carried out. Knowledge of geological strata and thermodynamic relationships is essential for setting up heat transport models. Therefore, this meant the starting point and preparations of this endeavour. The layer sequences were simplified in terms of a latter (simpler) manageability in the modeling environment. The results of these preliminary assessments are not included in a detailed manner as they have been already summarized by two previous works in the recent topic [4] [5].

The ultimate target of the study was to build a hydrodynamic model and assess the temperature potentials of a region with such geological and hydrogeological setup in terms of future utilization. The first results showed that beneath a volcanic cap rock thick clay-, marl assemblages are situated which temperatures can reach up to $40-50^{\circ} \mathrm{C}$. Due to the construction of the potential wells the establishment of a deep borehole heat exchanger system has been discarded due to the significant heat loss through the piping. The temperature is also considered too low for the initial costs of an enhanced geothermal system as neither fracture system nor free fluids are available at that zone. However, a single well circulation system is both space-saving and feasible technique, the aquifer layer extent not considered to be adequate for a long-term operation. Examining all the possibilities the establishment of a dual well circulation system in a form of a well-triplet was decided. From both side of well planning and modeling some information were available in a form or well books which was correlated and supplemented with literature and perquisite calculations. As most of the wells are not reaching the potential considered aquifer layers, overdrilling is required on the existing wells. The original and 
planned sections were also visualized by layouts which due to the formal restrictions of an article are not included but can be read in the final thesis work [6].

Groundwater modeling of the area showed that exploiting and re-injecting the same amount of $2000 \mathrm{~m} 3$ of water on a daily basis through 50 years results in a hydrodynamically stable and sustainable system within the aquifer layer. The heat transport modeling revealed that with the same amount of extracted, (approximately) $60^{\circ} \mathrm{C}$-, and re-injected $25^{\circ} \mathrm{C}$ water the system is long-term feasible up to 30 years without resting periods. Even so it is sustainable for a relatively long time implementation of resting phases is highly recommended since through the operating wells are distant and not directly affects each other's performance, however it may cause irreversible changes in their environment or other wells nearby. The current work did not cover the assessment of set aside periods as these strongly depends on the purpose of geothermal energy use. The lifetime of the system probably elongates if depletion by overexploitation is avoided and the time is given for the natural replenishment processes to take action. The present study intended to point out the identification of the knowledge gaps where scientific approaches and modern technical solutions could be implemented. The results of similar endeavours like the current work makes adaptation easier for incoming unusual conditions and helps to achieve sustainable water management goals in the future [7].

\section{References}

[1] Pelikán P., Less Gy., Kovács S., Pentelényi L., Sásdi L. (2005): A Bükk hegység földtana, Magyarország tájegységi térképsorozata, Magyar Állami Földtani Intézet, Budapest, p. 249

[2] https://www.energy.gov/sites/prod/files/guide_to_geothermal_heat_pumps (2020.12.11)

[3] Szücs P., Turai E., Vass P., Zákányi B., Ilyés Cs., Nyiri G., Fekete Zs., Miklos R., Mádai V., Móricz F., Szilvási M., Kilik R., Zákányiné Mészáros R. (2019): Re-utilizing possibilities of abandoned hydrocarbon wells in Northern Hungary; Proceedings of 46th Annual Congress of the International Association of Hydrogeologists, Málaga, 22nd - 27th September, 2019. p. 131

[4] Bretán D., Szücs P., Miklós R., Ilyés Cs. (2019): Geotermikus energia hasznosíthatósági lehetőségei a Bükkalja térségében meddő szénhidrogén termelő kutak átképzésével, International Jorunal of Engineering and Management Sciences (IJEMS) Vol. 4. (2019). No. 4, pp. 351-357 https://doi.org/10.21791/IJEMS.2019.4.40.

[5] Bretán D., Szücs P., Miklós R., Ilyés Cs. (2020): Geothermal energy utilization by revitalization of abandoned oil wells in a foreground of a mountainous region, Müszaki Földtudományi Közlemények Vol. 89 (1) pp. 347-356

[6] Bretán D., Szücs P., Miklós R. (2020): Geothermal energy utilization by revitalization of abandoned oil wells in the foreground of a mountainous region, Faculty of Earth Science and Engineering Institute of Environmental Management, University of Miskolc, Miskolc, p. 92

[7] Báldi A., Sugár É., Bozó L., Engloner A., Józsa J., Németh T., Szücs P., Vörös L. (2020): The Role of Water Sciences in Sustainability, Magyar tudomány 181(2020) 5, Akadémiai kiadó, Budapest, pp. 656-667 